\title{
NEONATAL CYSTIC FIBROSIS SCREENING IN LATVIA: A PILOT PROJECT
}

\author{
Baiba Lāce*,** Santa Grīnblate*, Liene Korṇejeva*,**, Vija Švābe ${ }^{\star * *}$, Ineta Grauduma*, \\ Pārsla Vēvere" ${ }^{* *}$ Rita Lugovska ${ }^{* *}$, Alvils Krams ${ }^{* * * *}$, and Agris Martinsons ${ }^{* * * * *}$ \\ * Department of Medical Biology and Genetics, Rīga Stradinš University, Dzirciema 16, Rīga, LV-1007, LATVIA \\ ** Children's Clinical University Hospital, Juglas iela 20, Rīga, LV-1079, LATVIA \\ *** Children's Clinical University Hospital, Vienības gatve 45, Rīga, LV-1004, LATVIA

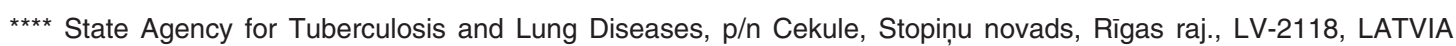 \\ ***** Pauls Stradinš̌ University Hospital, Pilsoṇu iela 13, Rīga, LV-1002, LATVIA
}

Communicated by Andrejs Ërglis

\begin{abstract}
Cystic fibrosis (CF) is one of the most common severe autosomal recessive diseases in the Northern European population affecting 1:2000-4000 individuals worldwide and 1:3300 in Latvia. Every year in Latvia since 1994, the approximate birth rate is 20,000 newborns per year, so theoretically there should be 6-8 new cases of CF per year. In Latvia, since 1998, there have been 49 patients with clinically confirmed diagnosis of CF. Recognition of a person with cystic fibrosis has always been a challenging task for clinicians, because of the constellation of symptoms, which can easily be misleading and explained by other aetiology. Therefore, in several countries, neonatal screening programmes using immunoreactive trypsinogen (IRT) have been introduced. The aim of this study was to evaluate the possible introduction of a neonatal IRT and DNA screening programme for diagnostic confirmation of cystic fibrosis in Latvian infants. IRT was measured in dried blood spots from 7,040 newborns, and DNA analysis for mutations dF508 and 394delTT performed for all individuals with increased IRT. Two persons suspected to have CF were identified, which is in accordance with population studies of CF frequency in Latvia. The estimated frequency of CF in Latvia of 1:3,520 corresponds to the average frequency in Europe. A mutation panel examining 230 mutations by APEX was applied to all samples with an IRT level above 100 $\mathrm{ng} / \mathrm{ml}$ and two patients with the diagnosis of CF were identified.
\end{abstract}

Key words: cystic fibrosis, neonatal screening, IRT/DNA.

\section{INTRODUCTION}

Cystic fibrosis (CF) is one of the most common severe autosomal recessive diseases in the Northern European population, affecting 1:2,000-4,000 individuals worldwide (Scriver et al., 2001). CF frequency in Latvia was estimated based on previous studies by Krumina et al. who reported it as $1: 3300$. CF is a complex disease affecting a number of organ systems including the genitourinary tract, respiratory tract, and causing pancreatic insufficiency (Ferec et al., 2006).

Cystic fibrosis is caused by numerous mutations in the CFTR (ABCC7) gene. Thus far, approximately 1,640 mutations have been identified (Anonymous, 2009). Phenylalanine deletion in the 508 position or dF508 is the most common mutation with highest incidence in Northern Europe reaching $70 \%$ (Karem et al., 1989). The contribution of the dF508 mutation to all CF mutations in Latvia is $61 \%$ (Krumina et al., 2001). Every year, since 1994, in Latvia, the approximate birth rate is 20,000 newborns per year, so theoretically there should be 6-8 new cases of CF per year (Svabe, 2001). Thus far in Latvia, since 1998, there have been 49 patients with clinically confirmed diagnosis of CF (Svabe et al., 2001), 162 cases had been registered by archive studies on post-mortem data overall in Latvia (Znotina et al., 2006).

Recognition of a person with cystic fibrosis has always been a challenging task for clinicians, because of the constellation of symptoms, which can easily be misleading and explained by other aetiology. Therefore, in several countries, neonatal screening programmes using immunoreactive trypsinogen (IRT) have been introduced (Hammond et al., 1991).

Immunoreactive trypsinogen screening is highly specific, but five percent of cases produce false negative results. Therefore, several tests should be added to confirm diagnosis so that patients may be appropriately referred to a $\mathrm{CF}$ centre (Wilcken et al., 2003). IRT could be followed by repeated IRT after three weeks (IRT/IRT). Its sensitivity is 
considered low at $80.2 \%$, and considerably increased sensitivity $(96 \%)$ has been observed for IRT complemented with DNA analysis (IRT/DNA) using a population-specific mutation panel with at least 24 mutations (Kloosterboer et al., 2009; Corbetta et al., 2002).

The immunoreactive trypsinogen test was developed to identify diseases affecting pancreatic function such as pancreatitis, pancreatic cancer, and CF. Trypsinogen is an enzyme secreted by the pancreas and is a precursor of trypsin. Trypsin breaks down protein in the duodenum (Scriver et al., 2001). Proposals for neonatal screening with IRT are often met with counter arguments about the cost-benefit of an expensive neonatal test followed by molecular analysis and failure to heal disease completely after its recognition. There have been several publications on long-term followup showing considerably better overall health of patients with cystic fibrosis, if they are treated early in comparison with delayed treatment, which may result for some in irreversible organ damage. It was concluded that $\mathrm{CF}$ patients identified in newborn screening programmes have better growth and reduced morbidity, with slower CF lung disease progression (Sims et al., 2007; Hammond et al., 1991).

The aim of this study was to evaluate possible introduction of a neonatal IRT/DNA screening and diagnostic confirmation programme for cystic fibrosis in Latvia.

\section{MATERIALS AND METHODS}

Immunoreactive trypsinogen was measured in the dried blood spots from 7,040 newborns (3,000 samples in 2007 and 4,040 samples in 2008).

IRT detection. Cut-off values for IRT in 2007 were 60 $\mathrm{ng} / \mathrm{ml}$ and in 2008 this was increased to $80 \mathrm{ng} / \mathrm{ml}$. Patients with increased IRT were invited to the Children's University Hospital Medical Genetics clinic to undergo blood sampling for further DNA analysis and a sweat test.

DNA analysis. To isolate DNA, dried blood samples were dissolved them in water, and subsequently incubated in methanol at room temperature for $15 \mathrm{~min}$. Denaturing was performed using $5 \mathrm{mM} \mathrm{NaOH}$ for $10 \mathrm{~min}$ at $100{ }^{\circ} \mathrm{C}$. Samples were chilled on ice and stored at $-20{ }^{\circ} \mathrm{C}$.

CFTR gene mutation analysis was performed first for the most common mutation, dF508, using PCR (polymerase chain reaction) and a heteroduplex method visualised by PAAG (polyacrylamide gel) electrophoresis. In cases when patients had increased IRT levels (100), but no dF508 mutation in either allele or only in one allele, APEX (Asper Biotech, Estonia) genotyping technology or an INNO-LiPA CFTR17+Tn test (Innogenetics, Belgium) was applied. INNO-LiPA CFTR17+Tn assays are line probe assays based on reverse hybridisation. This method can detect and identify $17 \mathrm{CF}$ related mutations and their wild-type sequences $(621+1 \mathrm{G} \rightarrow \mathrm{T}, 3849+10 \mathrm{kbC} \rightarrow \mathrm{T}, 2183 \mathrm{AA} \rightarrow \mathrm{G}$, 394delTT, 2789+5G $\rightarrow$ A, R1162X, 3659delC, R117H, R334W, R347P, G85E, 1078delT, A455E, 2143delT,
E60X, 2184delA, 711+5G $\rightarrow$ A), as well as the congenital bilateral absence of the vas deferens (CBAVD) related to Tn polymorphism. APEX (Arrayed Primer Extension) is a genotyping technology that combines the efficiency of a microarray-based assay with the comparable accuracy of Sanger dideoxy sequencing. This method can detect $230 \mathrm{CF}$ mutations. Both methods have standard protocols established by their manufacturer.

Research was approved by the Ethics Committee of the Republic of Latvia, No. 28.05.2003 A-10.

\section{RESULTS}

In 2007, there were 3,000 samples screened and $22(0.7 \%)$ persons were identified with IRT values above the cut-off level of $60 \mathrm{ng} / \mathrm{ml}$.

According to recent publications and kit manufacturer recommendations, in 2008, the cut-off level was increased to $80 \mathrm{ng} / \mathrm{ml} ; 4,040$ samples were screened and $13(0.32 \%)$ neonates identified (Table 1).

Table 1

IRT* VALUES IN NEWBORNS

\begin{tabular}{l|c|c|c|c}
\hline $\begin{array}{c}\text { Total } \\
\text { samples }\end{array}$ & $\begin{array}{c}\text { Number of } \\
\text { newborns with } \\
\text { elevated IRT }\end{array}$ & $\begin{array}{c}\text { IRT mean } \\
\mathrm{ng} / \mathrm{ml}\end{array}$ & $\begin{array}{c}\text { IRT max } \\
\mathrm{ng} / \mathrm{ml}\end{array}$ & $\begin{array}{c}\text { IRT min } \\
\mathrm{ng} / \mathrm{ml}\end{array}$ \\
\hline 3,000 & 22 & $\begin{array}{c}98.1 \\
\text { SD 33.9 }\end{array}$ & 184.3 & 59.9 \\
4,040 & 13 & $\begin{array}{r}187.4 \\
\text { SD } 146.4 \\
14\end{array}$ & 541.0 & 87.4 \\
$3,000 * *$ & 14 & SD 29.0 & \\
& 14 & 184.3 & 83.2
\end{tabular}

* IRt, immunoreactive trypsinogen; ** excluded samples with IRT values between 59.9-79.9. Cut-off value established as $80 \mathrm{ng} / \mathrm{ml}$.

Thirty-five neonates identified from IRT screening were tested for the most common mutation dF508 and 394delTT, and two heterozygous individuals (dF508/?) were identified. Both of them performed a sweat test, and in one patient, this test was positive, thus confirming diagnosis of cystic fibrosis in the first patient in Latvia through neonatal CF screening. The IRT value of the CF patient was $282 \mathrm{ng} / \mathrm{ml}$. Mutation screening performed for 230 mutations failed to identify the second mutation in the CFTR gene.

The second patient identified as heterozygous showed normal sweat test results. The IRT value was $87.4 \mathrm{ng} / \mathrm{ml}$ and it was concluded that the identification as heterozygous for dF508 mutation was a false positive.

The mutation del394delTT was not identified in patients and the most common 17 mutations from the INNO-LiPA panel were negative.

For the remaining persons with an elevated IRT $100 \mathrm{ng} / \mathrm{ml}$, mutation screening is still in progress. 


\section{DISCUSSION}

Cystic fibrosis is one of the most common life-threatening autosomal recessive disorders in the Western world. The estimated frequency of CF in Latvia of 1:3,520 corresponds to the previously calculated frequency in Latvia based on population studies, i.e., 1:3,300 (Krumina et al., 2001).

Worldwide, the dF508 mutation is responsible for approximately two-thirds $(61 \%)$ of all CF chromosomal aberrations. This common mutation varies from a maximum of $100 \%$ in the isolated Faroe Islands of Denmark, to a minimum of about $20 \%$ in Turkey (Bobadilla et al., 2002). In Latvia, the dF508 mutation is responsible for $61 \%$ of cases (Krumina et al., 2001). Whilst there is mostly great mutational heterogeneity in the remaining one-third of all alleles globally, there are partially private mutations arising de novo in families, and therefore population-based mutation panels do not recognise them.

In most European countries, neonatal CF screening has been recognised as important cost-effective health care provision based on CF frequency (Loeber, 2007).

The frequency of most CFTR mutations is highly variable and is often a function of the ethnic or geographic origin of the parents and grandparents of the affected child. Firstly, every country needs to determine their main population mutation panel. With the introduction of new technology such as APEX, which allows for the implementation of largescale, multi-mutation screening programmes, it is essential to have a complete understanding of which populations are carriers for selected mutations.

In a project using molecular methods, PCR, heteroduplex, reverse hybridisation, and APEX were not universal. For CF mutation detection, methods that are more complex are required. For example, PCR and heteroduplex methods are inexpensive, fast, specific, easy to analyse, and do not require expensive equipment. However, this method can detect only a few CF mutations. Reverse hybridisation and APEX methods are expensive and time-consuming, and, for APEX methods, require technical skill, but they can detect a comparatively large spectrum of mutations. The INNOLiPA CFTR kit does not include mutations that are frequent in the Latvian population and demonstrates that a different DNA analysis method to complement CF neonatal screening is required in Latvia.

IRT cut-off values should not be lowered below $80 \mathrm{ng} / \mathrm{ml}$. None of the individuals with lower IRT have been identified as CF patients. Lowering IRT cut-off values will only serve to increase the number of false positive results, thus aggravating more families with the concern of having children born with $\mathrm{CF}$ and increasing the total cost of neonatal $\mathrm{CF}$ screening programmes.

CF screening methodologies vary within and between countries worldwide as health care is a national undertaking. In Latvia between the years 2007-2008, 7,040 newborns period were tested to immunoreactive trypsinogen; in Austria, in 2004, 79,022 were screened for CF; in Germany 45,822, in Scotland 54,612 and in France 784,663 infants (Loeber, 2007).

There are different CF screening strategies in Europe: IRT, IRT/IRT, IRT/DNA (single (common) mutation), IRT/DNA (multiple mutations), IRT/DNA/IRT, IRT/DNA/failsafe step (sweat test), IRT/DNA/DNA (single (common) mutation/multiple mutations in second tier test). All current screening programmes use a measurement of immunoreactive trypsin as a primary screening test, and in most, a second tier test involves analysing DNA mutations (Wilcken et al., 2007). Different methods are used for mutation detection, for example, PCR (polymerase chain reaction), RFLP (restriction fragment length polymorphism), DGGE (denaturing gradient electrophoresis), APEX (Arrayed Primer Extension), reverse hybridisation and etc. The choice of DNA mutations and method depends on the genetic background in the region, and considerations of cost. No method or strategy will suit all regions. The IRT/DNA/sweat test model in Latvia was chosen mainly by unsatisfactory and aggravating response of parents of children with elevated IRT. The sweat test as a secondary step in CF neonatal screening can confirm $\mathrm{CF}$ diagnosis where mutation panel is limited.

\section{ACKNOWLEDGEMENTS}

The work was supported by the National Research Programme in Medicine 2006-2009, project nr.13 „Chronic respiratory diseases: timely and effective diagnostics, implementation of new treatment methods".

\section{REFERENCES}

Anonymous (2009). Cystic fibrosis transmembrane conductance regulator. http://www.ncbi.nlm.nih.gov/entrez/dispomim.cgi?id=602421

Bobadilla, J.,L., Farrell, M.H., Farrell, P.M. (2002). Applying CFTR molecular genetics to facilitate the diagnosis of cystic fibrosis through screening. Adv. Pediatr., 49, 131-190.

Corbetta, C., Seia, M., Bassotti, A., Ambrosioni, A., Giunta, A., Padoan, R. (2002). Screening for cystic fibrosis in newborn infants: Results of a pilot programme based on a two tier protocol (IRT/DNA/IRT) in the Italian population. J. Med. Screen, 60-63.

Ferec, C., Casals, T., Chuzhanova, N., Macek, M., Bienvenu, T. (2006). Gross genomic rearrangements involving deletions in the CFTR gene: Characterization of six new events from a large cohort of hitherto unidentified cystic fibrosis chromosomes and meta-analysis of the underlying mechanisms. Eur. J. Hum. Genet, 14, 567-576.

Hammond, K.B., Abman, S.H., Sokol, R.J., Accurso, F.J. (1991). Efficacy of statewide neonatal screening for cystic fibrosis by assay of trypsinogen concentrations. New Eng. J. Med., 769-774.

Kerem, B.S., Buchanan, J.A., Durie, P., Corey, M.L., Levison, H., Rommens, J.M., Buchwald, M., Tsui, L.C. (1989). DNA marker haplotype association with pancreatic insufficiency in cystic fibrosis. Amer. J. Hum. Genet, 44, 827-834.

Kloosterboer, M., Hoffman, G., Rock, M., Gershan, W., Laxova, A., Li, Z., Farrell, P. (2009). Clarification of laboratory and clinical variables that influence cystic fibrosis newborn screening with initial analysis of immunoreactive trypsinogen. Pediatrics, 338-346. 
Krumina, A., Kroshkina, V., Krumina, L., Svabe, V., Krumina, Z., Tamane, I., Baumanis, V. (2001). Cystic fibrosis mutation dF508 in the Latvian population. RSU/AML Scientific Proceedings, 161-166.

Loeber, J.G. (2007). Neonatal screening in Europe; the situation in 2004. J. Inherit. Metab. Dis., 30, 430-438.

Scriver, C.R., Beaudet, A.L., Sly, W.S., Valle, D. (2001). Cystic fibrosis. In: The Metabolic and Molecular bases of Inherited Disease. New York: McGraw-Hill Medical Publishing Division, $8^{\text {th }}$ edition, Vol. 3, 5121-5173.

Sims, E.J., Clark, A., McCormick, J., Mehta, G., Connett, G., Mehta, A. (2007). United Kingdom Cystic Fibrosis Database Steering Committee.
Cystic fibrosis diagnosed after 2 months of age leads to worse outcomes and requires more therapy. Pediatrics, 119(1), 19-28.

Svabe, V., Krumina, A. (2001). Latvijas Cistiskās fibrozes slimnieku klīniskā stāvokḷa novērtējums [Evaluation of CF patients' clinical symptoms in Latvia]. RSU/AML Scientific Proceedings, 128-130.

Wilcken, B., Wiley, V. (2003). Newborn screening methods for cystic fibrosis. Paediatr. Respir. Rev., 272-277.

Znotina, I., Svabe, V., Teibe U. (2006). Cistiskās fibrozes slimnieku dzīvildzes izmainas Latvijā atkarībā no terapijas [Therapy influence to life expectancy of CF patients in Latvia]. RSU/AML Scientific Proceedings, $345-349$.

Received 11 July 2009

\section{JAUNDZIMUŠO CISTISKĀS FIBROZES SKRĪNINGA PILOTPROJEKTS LATVIJĀ}

Cistiskā fibroze $(\mathrm{CF})$ ir viena no biežākajām autosomāli recesīvajām slimībām, kas Ziemeḷeiropas populācijā sastopama 1:2000-4000 personām, Latvijā tā sastopama 1:3300 personām. Kopš 1994. gada Latvijā katru gadu piedzimst apmēram 20000 jaundzimušo, teorētiski sagaidāmais CF pacientu skaits ir 6-8, bet no 1998. gada Latvijā klīniski diagnosticēti 49 CF pacienti. CF nav raksturīgi specifiski simptomi, tāpēc slimības diagnostika sagādā grūtības. Vairākās valstīs ir ieviests jaundzimušo CF skrīnings. Projekta mērḳis bija ieviest Latvijā CF jaundzimušo skrīningu, izmantojot imunoreaktīiā tripsinogēna (IRT) noteikšanu, ko papildina DNS diagnostika. IRT tika noteikts 7040 jaundzimušajiem, visiem ar paaugstinātu IRT līmeni veica dF508 un 394delTT mutāciju analīzi. Projekta rezultātā tika identificēti divi jaundzimušie dF508 heterozigoti, kas atbilst teorētiski sagaidāmai CF sastopamībai Latvijā un Eiropā 1: 3520. Pacientiem, kuriem IRT līmenis bija augstāks par $100 \mathrm{ng} / \mathrm{ml}$, veica 230 mutāciju paneḷa analīzi, izmantojot APEX tehnolog̣iju, un CF diagnoze tika apstiprināta diviem pacientiem. 